Int. J. Electrochem. Sci., 13 (2018) 2617 - 2626

\title{
Development of a Graphene Based Electrochemical Sensor for the Determination of 9-hydroxyrisperidone in Human Blood Plasma
}

\author{
Wenying Zhang* and Yanping Wang \\ Department of Laboratory Medicine, Tianjin Anding Hospital, Tianjin, 300222, P.R. China \\ *E-mail: wenyingzhangsally@163.com
}

doi: $10.20964 / 2018.03 .14$

Received: 15 November 2017 / Accepted: 4 January 2018 / Published: 5 February 2018

This work reports the preparation of a 9-hydroxyrisperidone amperometric biosensor using a glassy carbon electrode (GCE) modified with reduced graphene oxide wrapped hierarchical $\mathrm{TiO}_{2}(\mathrm{RGO}-$ $\mathrm{TiO}_{2}$ ) nanohybrid. In addition, the electro catalytic behaviour of the biosensor to the oxidisation of 9hydroxyrisperidone was studied using amperometric and cyclic voltammetry (CV) measurements. The low oxidation potential and enhanced current response of the $\mathrm{RGO}-\mathrm{TiO}_{2}$ modified GCE resulted from the synergistic effects of $\mathrm{TiO}_{2}$ and RGO. For the analysis of the 9-hydroxyrisperidone, the developed biosensor has a low limit of detection (LOD) of $0.52 \mathrm{ng} / \mathrm{mL}$ and a wide linear detection range of 1 to $1500 \mathrm{ng} / \mathrm{mL}$. Therefore, our developed biosensor had the potential for use in the practical detection of 9-hydroxyrisperidone in human blood plasma specimens.

Keywords: 9-hydroxyrisperidone; $\mathrm{TiO}_{2}$; Graphene; Human blood plasma; Electrochemical sensor

\section{$\underline{\text { FULL TEXT }}$}

(C) 2018 The Authors. Published by ESG (www.electrochemsci.org). This article is an open access article distributed under the terms and conditions of the Creative Commons Attribution license (http://creativecommons.org/licenses/by/4.0/). 